Vol. 2, No. 2, 2020

https://doi.org/10.23939/jtbp2020.02.092

Orest Voznyak, Yuriy Yurkevych, Iryna Sukholova, Oleksandr Dovbush, Mariana Kasynets

\title{
THERMALLY CONDUCTIVE COST OF THE HEAT-INSULATING MATERIALS
}

\author{
Lviv Polytechnic National University, \\ Department of Heat and Gas Supply and Ventilation, \\ orest.voznyak@i.ua
}

(C) Voznyak O., Yurkevych Yu., Sukholova I., Dovbush O., Kasynets M., 2020

The article presents the results of theoretical research to achieve the maximum effect in determination of the economically feasible level of buildings thermal protection. It must be optimal both thermally and economically, an indicator of which there are the costs. Graphical and analytical dependences are given. The research results substantiate the maximum effect when different thermal insulating materials are used. The aim is to increase the efficiency of energy saving measures, reduce their cost by optimizing the cost of thermal energy and insulating materials, determining the optimization criteria and justification for choice the optimal insulating material and its thickness, and determining the optimal thermal resistance, identifying ways to improve energy efficiency and substantiation of the calculation method. One of the most common thermal renovation measures, namely insulation of external walls, is considered. An economic assessment has been conducted, which is an important factor in a certain energy-saving proposition. The solution of the problem is presented, which includes two stages. The result of the first stage is the selection of the optimal heat-insulating material. The second stage is a substantiation of economically expedient thickness of the heatinsulating material. The obtained results make it possible to increase the efficiency of energy saving in thermal renovation of buildings taking into account both energy and economic aspects. In this paper the results of mathematical provement of such factor importance as the thermally conductive cost of the heat-insulating material at their thickness optimization are presented. Determining for the establishment of the normative thermal resistance in the future is the ratio of the cost of thermal energy to the thermal conductivity of the insulating material.

Key words: heat-insulating materials, capital investments, specific investments, energy saving, reduced costs, thermally conductive cost, specific thermally conductive cost.

\section{Introduction}

The physical state of the air environment in building rooms and technological premises is characterized by the different microclimate parameters which are supported by heating and ventilation system. The comfort conditions at first are defined by the air internal temperature and air velocity (Dovhaliuk \& Mileikovskyi, 2008; Voznyak et al., 2005; Kapalo et al., 2018). The normative characteristics of indoor air must be provided in the working area of the room, since the fact that the sanitaryhygienic parameters of the internal microclimate of the rooms responce to the physiological needs of a human depends, to a large extent, on their health and efficiency of work (Gumen et al., 2016; Dovhaliuk \& Mileikovskyi, 2007).

In 2016, the State Building Norms of Ukraine "Thermal Insulation of Buildings" became mandatory insteag DBN "Thermal Insulation of Buildings" 2006 (DBN B.2.6-31:2016). These DBN provide for the development of the house energy passport at the design stage of buildings and structures projects, as well during its reconstruction (Basok et al., 2014; Basok et al., 2016). The energy passport of the existing constructions is developed on the basis of the house energy audit data and in case of new 
construction - on the basis of the design documentation analysis, and thus the class of energy efficiency is appropriated (Bilous et al., 2018; Bilous et al., 2016).

Since 2017, the law "On energy efficiency of buildings" has been in force in Ukraine. This Law defines the legal, socio-economic and organizational principles of activities in the field of energy efficiency of buildings and is aimed at reducing energy consumption in buildings. Energy efficiency of buildings is defined in accordance to the methodology developed taking into account the demands of legislation of the European Union, Energy Community, harmonized European standards in the area of buildings energy efficiency and approved by the central authority management that ensures state policy in construction sphere (Buyak et al., 2017; Deshko et al., 2016).

Therefore, heat consumption for the houses heating should be significantly reduced due to carrying out their thermal modernization (Voznyak et al., 2005; Voznyak et al., 2017). To achieve the maximum effect, it is necessary to define the cost-effective level of thermal protection of buildings, that must be optimal thermally and economically, an indicator of which can be reduced costs (Voznyak et al., 2010; Voznyak et al., 2018). As a result, the consumer would be able to free up money for heating, and in addition, the optimization of the level of thermal protection provides significant energy savings (Voznyak et al., 2018; Voznyak et al., 2019).

To implement these tasks there is a need to increase energy efficiency, increase profits from the implementation of thermal renovation measures in the choice of insulation materials, and substantiation of the calculation method.

\section{Target of this article}

The aim of the work is to increase the efficiency of energy saving measures, reduce their cost by optimizing the cost of thermal energy and insulation materials, determine the optimization criteria and justify the choice of optimal insulation material and its thickness, and determine the optimal thermal resistance, identify ways to improve energy efficiency. and substantiation of the calculation method.

\section{Techniques used}

In DSTU Б B.2.6-189:2013 "Methods of selection of thermal insulation material for building insulation" provides guidelines for calculating the reduced heat transfer resistance of opaque enclosing structures and determining the required thickness of the thermal insulation layer. However, these provisions do not take into account economic aspects when choosing a thermal insulation material.

In this article the means and ways of optimization of introduction of energy saving taking into account the cost of thermal energy and heat-insulating materials are developed. In this case, the most interesting are those measures that are effective in terms of heat and at the same time can be implemented at minimal cost, ie have a short payback period. One of the most common thermal renovation measures is insulation of external walls. An important factor in a certain energy-saving supply is economic evaluation. The solution of this problem includes two stages.

The first stage: the choice of the optimal insulation material. To do this, consider a multilayer structure of the wall of the house, which can be further insulated with one of the insulating fibrous or polymeric materials (Table 1). The cost of thermal insulation materials is accepted as the average value of the commercial offer for these materials of the largest retail chains of building materials in Ukraine for the third quarter of 2020.

The use of a thermal insulation material $(A$ or $B$ ) should be considered in terms of providing them with equivalent thermal conditions, namely a single thermal resistance of thermal conductivity $R=1 \mathrm{~m}^{2} \mathrm{~K} / \mathrm{Wt}$. Accordingly, their thickness will be different $\delta_{\mathrm{A}}$, and $\delta_{\mathrm{B}}$, specific volume $V_{A}$ and $V_{B}$ (with a single wall surface $1 \mathrm{~m}^{2}$ ), as well as the unit cost $C_{A}$ and $C_{B}$ elected materials, calculated on the basis of data. Because provided $R=1 \mathrm{~m}^{2} \mathrm{~K} / \mathrm{Wt}$, that is $\delta_{\mathrm{i}} / \lambda_{\mathrm{i}}=1 \mathrm{~m}^{2} \mathrm{~K} / \mathrm{Wt}$, there is a need to investigate 
the thermal properties of thermal insulation materials, taking into account their cost. If the unit cost of the material $C_{\mathrm{i}}, \mathrm{UAH} / \mathrm{m}^{3}$, then its total cost $K_{\mathrm{i}} \mathrm{UAH} / \mathrm{m}^{2}$, is proportional to the thickness $\delta_{\mathrm{i}}: K_{\mathrm{i}}=C_{\mathrm{i}} \delta_{\mathrm{i}}$.

Table 1

Technical and economical characteristics

\begin{tabular}{|c|l|c|c|c|}
\hline No. & \multicolumn{1}{|c|}{ Назва матеріалу } & $\begin{array}{r}\text { Heat } \\
\text { conductivity } \\
\lambda_{i}, \mathrm{Wt} /(\mathrm{mK})\end{array}$ & $\begin{array}{c}\text { Insulation } \\
\text { thickness } \\
\delta_{i}, \mathrm{~mm}\end{array}$ & $\begin{array}{c}\text { Specific } \\
\text { investment } \\
S I, U A H /\left(\mathrm{m}^{3}\right)\end{array}$ \\
\hline 1 & Mineral wool Rockwool Frontrock MAX & 0.036 & 100 & 2800 \\
\hline 2 & Mineral wool Beltep facade PRO & 0.035 & 100 & 2320 \\
\hline 3 & Polyfoam Greinplast GP-25-11 & 0.041 & 100 & 2200 \\
\hline 4 & Polyfoam Shpaten 35 Fasad & 0.040 & 100 & 2300 \\
\hline 5 & Polyfoam Ferozit 25 Exstra & 0.041 & 100 & 1817 \\
\hline 6 & Extruded expanded polystyrene Bateplex (XPS) & 0.030 & 50 & 1910 \\
\hline 7 & Extruded expanded polystyrene Eastplex (XPS) & 0.029 & 50 & 1800 \\
\hline 8 & Extruded expanded polystyrene Penoplex (XPS) & 0.029 & 100 & 2214 \\
\hline
\end{tabular}

Analyzing Table 1, it should be noted that the foam Greinplast GP-25-11 and Ferozit 25 Exstra have the same thermal conductivity, but foam Greinplast GP-25-11 is more expensive, so may not be optimal. Similarly, when comparing extruded expanded polystyrene Eastplex (XPS) and Penoplex (XPS), the Penoplex (XPS) should be rejected.

However, only the economic aspect characterizes the material insufficiently, unilaterally. It is advisable to cover the problem in the complex, namely to take into account both the economic and thermal conductivity of the material. Comparing the ratio of unit cost $\beta=C_{A} / C_{B}$ any two materials $A$ and $B$ provided that they provide a single thermal resistance of thermal conductivity $R_{\mathrm{i}}=1 \mathrm{~m}^{2} \mathrm{~K} / \mathrm{Wt}$, consider the ratio of thermal conductivity $\alpha=\lambda_{B} / \lambda_{A}$. It should be noted that the thermal conductivity of the more efficient material $A$ is lower and the cost is higher. Value for money $K_{A} / K_{B}$ any two materials $A$ and $B$ we obtain on condition that they provide a single thermal resistance of thermal conductivity $R_{\mathrm{i}}=1 \mathrm{~m}^{2} \mathrm{~K} / \mathrm{Wt}$ from the formula (1):

$$
K_{B}=K_{A} \frac{\alpha}{\beta} .
$$

Based on the analysis of formula (1), we state: there are three options for the ratio of values $\alpha$ and $\beta$, namely: $\alpha=\beta, \alpha<\beta, \alpha>\beta$. If $\alpha=\beta$, then $K_{\mathrm{A}}=K_{\mathrm{B}}$, therefore the choice of heat-insulating material is equivalent. If $\alpha<\beta$, then $K_{A}<K_{B}$, which means that material $B$ is cheaper when they provide a single thermal resistance of thermal conductivity $R_{\mathrm{i}}=1 \mathrm{~m}^{2} \mathrm{~K} / \mathrm{Wt}$, and if $\alpha>\beta$, then $K_{A}>K_{B}$, then, accordingly, this material is more expensive.

Therefore, there is a need to introduce such a concept as the specific thermal conductivity of the material, because its total cost depends on both the specific cost of the material and its thermal conductivity. The dimension of this value is as follows: $U A H \mathrm{Wt} /\left(\mathrm{m} \cdot \mathrm{K} \cdot \mathrm{m}^{3}\right)$, which corresponds to the definition. It should be noted that the expression in parentheses reflects the physical content of the specific thermal conductivity of the material and its relationship to the specific cost. This fact is taken into account in Table 2.

Analysis of Table 2 shows that the optimal material from a complex point of view of thermal conductivity is extruded expanded polystyrene Eastplex (XPS) with thermal conductivity $\lambda=0.029 \mathrm{Wt} /(\mathrm{mK})$ and thickness $\delta=50 \mathrm{~mm}$. 
Specific thermally conductive cost of materials

\begin{tabular}{|c|l|c|c|c|c|}
\hline No. & \multicolumn{1}{|c|}{ Назва матеріалy } & $\begin{array}{c}\text { Heat } \\
\text { conductivity } \\
\lambda_{\mathrm{i}}, \\
\mathrm{Wt} /(\mathrm{mK})\end{array}$ & $\begin{array}{c}\text { Insulation } \\
\text { thickness } \\
\delta_{\mathrm{i}}, \\
\mathrm{m}\end{array}$ & $\begin{array}{c}\text { Specific } \\
\text { investment } \\
S I \\
\mathrm{UAH} /\left(\mathrm{m}^{3}\right)\end{array}$ & $\begin{array}{c}\text { Specific thermally } \\
\text { conductive cost } \\
T C C \\
\mathrm{UAH} \mathrm{Wt} /\left(\mathrm{mKm}^{3}\right)\end{array}$ \\
\hline 1 & Mineral wool Rockwool Frontrock MAX & 0.036 & 100 & 2800 & 100,8 \\
\hline 2 & Mineral wool Beltep facade PRO & 0.035 & 100 & 2320 & 81,2 \\
\hline 3 & Polyfoam Shpaten 35 Fasad & 0.040 & 100 & 2300 & 92,0 \\
\hline 4 & Polyfoam Ferozit 25 Exstra & 0.041 & 100 & 1817 & 74,5 \\
\hline 5 & $\begin{array}{l}\text { Extruded expanded polystyrene Bateplex } \\
\text { (XPS) }\end{array}$ & 0.030 & 50 & 1910 & 57,3 \\
\hline 6 & Extruded expanded polystyrene Eastplex (XPS) & 0.029 & 50 & 1800 & 52,2 \\
\hline
\end{tabular}

This is the result of the first stage of the solution.

The second stage: substantiation of economically feasible thickness of heat-insulating material. The task is as follows: the outer wall must be further insulated with a layer of insulating material with thermal conductivity $\lambda_{\text {ins }}$ economically feasible thickness $\delta_{\text {ins }}^{\text {opt }}$, the brand of which is determined as a result of the first stage of the solution.

The magnitude of specific heat loss to insulation $q_{0},\left[\mathrm{Wt} / \mathrm{m}^{2}\right]$ :

$$
q_{o}=\frac{t_{\mathrm{int}}-t_{\text {ext }}}{R_{o}}
$$

and, accordingly, after warming $q,\left[\mathrm{Wt} / \mathrm{m}^{2}\right]$ :

$$
q=\frac{t_{\text {int }}-t_{\text {ext }}}{R_{n}+\frac{\delta_{\text {ins }}}{\lambda_{\text {ins }}}}
$$

Heat saving $\Delta q=q_{o}-q$ :

$$
\Delta q=t_{\text {int }}-t_{\text {ext }} \frac{\delta_{\text {ins }}}{R_{n}^{2} \lambda_{\text {ins }}+R_{o} \delta_{i n s}} .
$$

Annual savings of specific heat during the heating period $\Delta q_{h p}$ :

$$
\Delta q_{h p}=\Delta q \frac{t_{\text {int }}-t_{h p}}{t_{\text {int }}-t_{\text {ext }}}
$$

Annual savings due to annual heat savings $\Delta B_{e c}^{\text {year }} \mathrm{UAH} /\left(\mathrm{m}^{2}\right.$ year $)$ :

$$
\Delta B_{e c}^{\text {year }}=\Delta q_{h} \cdot P_{T E},
$$

where $P_{T E}$ - the cost of thermal energy, $P_{T E}=219.3 \mathrm{UAH} / \mathrm{GJ}$ (conditionally variable part of the tariff for subscribers of residential buildings with domestic and apartment heat meters - 921.12 UAH/Gcal).

Annual investment costs for thermal modernization $O C$ :

$$
O C=\frac{1}{T} \sum_{i=1}^{n} I_{i}
$$

where $T$ - payback period of thermal renovation measures [year]; $\sum_{i=1}^{n} I_{i}$ - cost of materials, installation (salary), transportation costs and other financial costs,UAH. 
Based on these data, we build a graph (Fig. 1). Fig. 1 shows the dependence on the thermal resistance of the insulating material $R$ investment costs $A I$ for thermal renovation activities with materials $A$ and $B$ (according to the line 1a and 1b), operating costs $O C$ (line 2) and annual reduced costs $T C$ for these materials (lines $3 \mathrm{a}$ and $3 \mathrm{~b}$ respectively). The value of the reduced costs has a minimum point, which corresponds to the optimal values of thermal resistance $R_{\text {opt }}$ and reduced costs $T C_{\text {opt. }}$. Fig. 1 shows the geometric interpretation of finding the optimal points for different materials $A_{\text {opt }}$ and $B_{\text {opt }}$ Value $R_{\text {opt }}$ and $T C_{\text {opt }}$ are determined analytically after differentiation of the expression for the reduced costs and equating it to zero.

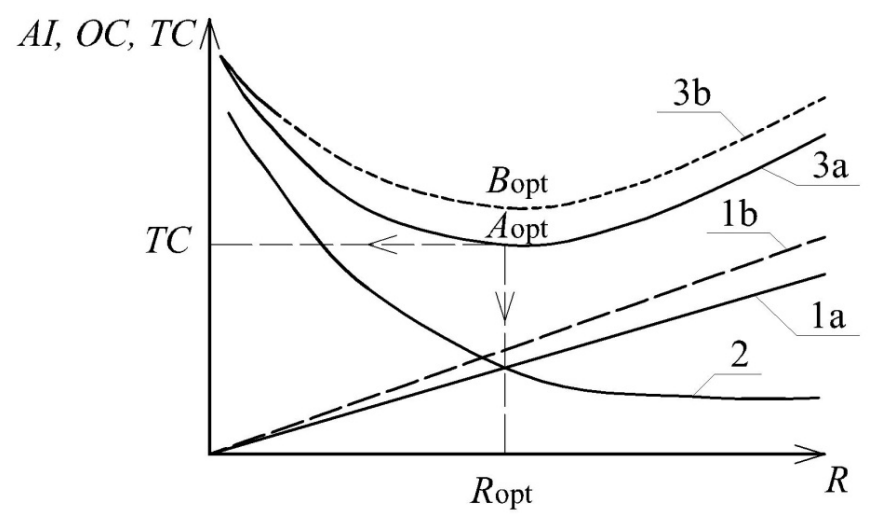

Fig. 1. Dependence of various financial costs on thermal resistance $R$ :

$1 a$ and $1 b$ - annual investment costs AI respectively for materials $A$ and $B$;

2 - operating costs, OC; 3 - reduced costs, TC

To obtain the result of the second stage of the solution, it is necessary to investigate the function of the reduced costs for the presence of a minimum point

$$
T C_{i}=\frac{b_{i}}{T} R+\frac{a}{R},
$$

where $a$-coefficient depending on the cost of thermal energy, $\left(\mathrm{UAH} \mathrm{m}^{2} \mathrm{~K}\right) /($ year Wt);

$b_{\mathrm{i}}$ - теплопровідна вартість, (UAH Wt) / $\left(\mathrm{m}^{2} \mathrm{~K}\right)$.

In this case, the terms of equation (8) are, respectively, capital investment (total annual cost of thermal insulation material) and operating costs (specific annual cost of thermal energy to maintain a given room temperature (internal temperature) $t_{\text {int }},{ }^{\circ} \mathrm{C}$ ).

After differentiation of expression (8) we obtain economically feasible thermal resistance $R_{\text {opt }}$ :

$$
R_{o p t}=\sqrt{\frac{a \cdot T}{b_{i}}} .
$$

Analysis of formula (9) shows that the rise in price of thermal energy leads to an increase in optimal thermal resistance, and thus to the need to increase its regulatory value. A similar effect leads to a decrease in the specific thermal conductivity of the insulating material, but there is usually a tendency to increase its cost. Therefore, the ratio of the coefficients $a$ and $b$, ie the cost of thermal energy to the thermal conductivity of the thermal insulation material, is decisive. This factor must be taken into account when normalizing the thermal resistance for the future.

\section{Conclusions}

On the basis of the obtained results we state:

- the optimal heat-insulating material from 8 considered at the set initial data is extruded expanded polystyrene Eastplex (XPS) with thermal conductivity $\lambda=0.029 \mathrm{Wt} /(\mathrm{mK})$ and thickness $\delta=50 \mathrm{~mm}$; 
- when choosing a thermal insulation material should be guided by its specific thermal conductivity, which combines its thermal properties and economic characteristics;

- the method of determining the optimal point under constant prices, ie the optimal specific reduced costs and the optimal thermal resistance are presented;

- the rise in price of thermal energy leads to an increase in optimal thermal resistance, and hence to the need to increase its regulatory value;

- determining for the establishment of the normative thermal resistance in the future is the ratio of the cost of thermal energy to the thermal conductivity of the insulating material.

\section{References}

Basok, B., Davydenko, B., Farenuyk, G., \& Goncharuk, S. (2014). Computational Modeling of the Temperature Regime in a Room with a Two-Panel Radiator. Journal of Engineering Physics and Thermophysics, Vol. 87, Issue 6, 1433-1437.

Basok, B., Davydenko, B., Isaev, S., Goncharuk, S., \& Kuzhel', L. (2016). Numerical Modeling of Heat Transfer Through a Triple-Pane Window. Journal of Engineering Physics and Thermophysics, Vol. 89, Issue 5, 1, 12771283.

Bilous, I., Deshko, V., \& Sukhodub, I. (2018). Parametric analysis of external and internal factors influence on building energy performance using non-linear multivariate regression models. Journal of Building Engineering, Vol. 20, 327-336.

Bilous, I., Deshko, V., \& Sukhodub, I. (2016). Building inside air temperature parametric study. Magazine of Civil Engineering, Vol. 68, Issue 8, 65-75.

Buyak, N., Deshko, V., \& Sukhodub, I. (2017). Buildings energy use and human thermal comfort according to energy and exergy approach. Energy and Buildings, Vol. 146, 1, 172-181.

Deshko, V., \& Buyak, N. (2016). A model of human thermal comfort for analysing the energy performance of buildings. Eastern-European Journal of Enterprise Technologies, Vol. 4, Issue 8-82, 42-48.

Dovhaliuk, V. B., \& Mileikovskyi, V. O. (2007). Efficiency of organization of air exchange in heat-stressed premises in compressed conditions, Journal: Building of Ukraine, No. 3, 36. (in Ukrainian).

Dovhaliuk, V. B., \& Mileikovskyi, V. O. (2008). Estimated model of non-isothermal stream, which is laid out on a convex cylindrical surface. Ventilation, Illumination and Heat and Gas Supply: Scientific and Technical Collection, Issue 12, Kyiv: KNUBA, 11-32 (in Ukrainian).

Gumen, O. M., Dovhaliuk, V. B., \& Mileikovskyi, V. O. (2016). Determination of the intensity of turbulence of streams with large-scale vortices on the basis of geometric and kinematic analysis of macrostructure. Proc. of Lviv Polytechnic National University: The theory and building practice, No. 844, 76-83 (in Ukrainian).

Kapalo, P., Voznyak, O., Yurkevych, Yu., Myroniuk, Kh., \& Sukholova, I. (2018). Ensuring comfort microclimate in the classrooms under condition of the required air exchange. Eastern European Journal of Enterprise Technologies, Vol. 5/10 (95), 6-14.

Voznyak, O., Myroniuk, Kh., \& Dovbush, O. (2005). Relationship between a Person Heat Exchange and Indoor Climate. Selected scientific Papers $10^{\text {th }}$ Rzeszow-Lviv-Kosice Conference 2005 Supplementary Issue. Technical University of Kosice. 148-152.

Voznyak, O. T., Sukholova, I. E., Savchenko, O. O., \& Dovbush, O. M. (2017). Thermal renovation of the air conditioning system of industrial premises. Bulletin of the Odessa State Academy of Civil Engineering and Architecture, No. 68, 114-120 (in Ukrainian).

Voznyak, O. T, Yurkevych, Yu. S., \& Zhelykh, V. M. (2010). Analysis of economic effects in thermal modernization of buildings. Ventilation, Illumination and Heat and Gas Supply: Scientific and Technical Collection. KNUBA, 14, 79-89 (in Ukrainian).

Zhelykh, V., Voznyak, O., Kozak, Kh., Dovbush, O., \& Kasynets, M. Civil buildings heating system thermal renewal. Proc. of Lviv Polytechnic National University: The theory and building practice. No. 1(2), 7-13.

Voznyak, O. T., Savchenko, O. O., Yurkevych, Yu. S., \& Dovbush, O. M. (2018). Thermal renovation of the gas supply system of industrial premises. International. scientific and technical Journal: Modern technologies, materials and structures in construction. Vinnytsia NTU, 2(25), 178-184 (in Ukrainian).

Voznyak, O. T., Sukholova, I. E., Yurkevych, Yu. S., \& Dovbush, O. M. (2018). Thermal modernization of industrial rooms air conditioning system. Proc. of Lviv Polytechnic National University: The theory and building practice, No. 888, 36-42. 
Thermal insulation of buildings. DBN B.2.6-31:2016. K.: Ministry of Construction of Architecture and Housing and Communal Services of Ukraine (in Ukrainian).

Methods of selection of heat-insulating material for warming of buildings. DSTU Б В.2.6-189:2013. K.: Ministry of Regional Development of Ukraine (in Ukrainian).

О. Т. Возняк, Ю. С. Юркевич, І. Є. Сухолова, О. М. Довбуш, М. Є. Касинець Національний університет “Львівська політехніка", кафедра теплогазопостачання і вентиляції

\title{
ТЕПЛОПРОВІДНА ВАРТІСТЬ ТЕПЛОІЗОЛЯЦІЙНИХ МАТЕРІАЛІВ
}

\author{
(С) Возняк О. Т., Юркевич Ю. С., Сухолова I. Є., Довбуи О. М., Касинецьь М. С., 2020
}

У статті представлені результати теоретичних досліджень досягнення максимального ефекту при визначенні економічно доцільного рівня теплозахисту будинків. Він повинен бути оптимальним і в теплотехнічному, і в економічному сенсі. Показником чого виступають зазначені затрати. Наведено графічні та аналітичні залежності. Результатами досліджень обгрунтовано отримання максимального ефекту при застосуванні різних теплоізоляційних матеріалів. Мета роботи - підвищити ефективність енергоощадних заходів, досягнути зниження їхньої вартості за рахунок оптимізації у співвідношенні вартості теплової енергії та теплоізоляційних матеріалів, визначити критерій оптимізації та обгрунтувати вибір оптимального теплоізоляційного матеріалу і його товщини та визначити оптимальний термічний опір, виявити шляхи підвищення ефективності енергоощадності на перспективу та обгрунтувати методику розрахунку. Розглянуто один із найпоширеніших термореноваційних заходів, а саме утеплення зовнішніх стін. Проведено економічну оцінку, що $\epsilon$ важливим чинником певної енергоощадної пропозиції. Представлено розв'язок поставленої задачі, який охоплює дві стадії. Результатом на першій стадії є вибір оптимального матеріалу ізоляції. Друга стадія - це обгрунтування економічно доцільної товщини теплоізоляційного матеріалу. Отримані результати дають змогу досягнути підвищення ефективності енергоощадності при термореновації будинків і в енергетичному, і в економічному аспектах. У цій статті представлено результати математичного обгрунтування важливості такого чинника як теплопровідна вартість теплоізоляційних матеріалів при оптимізації їхньої товщини.

Ключові слова: теплоізоляційні матеріали, капіталовкладення, питомі інвестиції, енергоощадність, приведені затрати, теплопровідна вартість, питома теплопровідна вартість. 